\title{
Litauens traumatiserende historie og forebygging av selvmord
}

Ved Danutè Gailienè

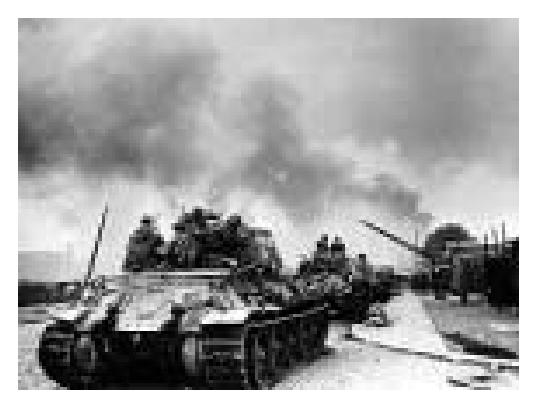

I hele femti år, fra 1940 til 1990, opplevde Litauen i likhet med de andre baltiske statene å være okkupert av henholdsvis Sovjetunionen og Nazi-Tyskland. I dag kan vi slå fast at det hadde en sterkt traumatiserende effekt på det politisk undertrykte folket og samfunnet som helhet. Resultatene av denne traumatiseringen er følbare den dag i dag, og de må også tas i betraktning når det legges opp en strategi for forebygging av selvmord i Litauen.

1939 undertegnet Sovjetunionen og $\mathrm{N}$ azi-Tyskland M olotov-Ribbentroppakten, som delte Europa i to interessesfærer. Det ble bestemt at Litauen skulle tilhøre sovjetsfæren. Sommeren 1940, og allerede før den formelle innlemmelsen av Litauen i Sovjetunionen, ble det iverksatt massearrestasjoner og -deportasjoner. O frene var de mest aktive og velutdannede samfunn smedlemmene: offentlige tjenestemenn, lærere, professorer, prester, høyskole- og universitetsstudenter, gårdbrukere, medlemmer av organi sasjoner og politiske partier, samt andre "sovjetfiendtlige el ementer".

I juni 1941 ble Litauen okkupert av $\mathrm{N}$ azi-Tyskland, og ved hjelp av lokale kollaboratører begynte masseutryddelsen av jødene. Den sovjetiske hæren gjenvant sin kontroll over Litauen i 1944, og dermed startet en ny okkupasjonstid som skulle vare i bortimot femti år.

O ver en million mennesker, eller rundt 30 prosent av befolkningen, ble deportert, dømt til døden, fengslet eller tvunget til å emigrere.

Perioden med den mest brutale undertrykkingen varte frem til Stalins død i 1953. H vert år ble tusenvis av mennesker fra Litauen sendt til Gulag-leirene eller deportert i kuvogner til Sibir, der de ble påført alvorlige fysiske og psykiske lidelser. Den årlige dødelighetsraten i G ulag var svært høy i perioden 1941 til 1944. Den lå på over 50 prosent og var i enkelte leire så høy som 93 prosent. Fra 1941 til 1944 døde de første 8000 politiske fangene fra Litauen av sult og utmattelse. Fra 1945 til 1947 omkom rundt 37000 mennesker i leirene (A nusauskas, 1996).

\section{Forfølgelse etter fengsling og deportasjon}

De fleste politisk undertrykte personene vendte aldri tilbake til Litauen: $N$ oen døde i Sibir, mens andre ikke fikk lov til å komme tilbake igjen. Et spesielt trekk ved det sovjetiske undertrykkingssystemet var at tidligere deporterte samt folk som hadde overlevd oppholdet i arbeidsleirene, måtte fortsette å lide etter at de var ferdige med sine deportasjons- eller fengselsdommer fordi de fortsatt ble betraktet som fiender av regimet. $M$ ange av dem som vendte tilbake til Litauen, var ikke i stand til å skaffe seg jobber eller permanent opphold der. De fikk forbud mot å bosette seg i større bysentre eller på de stedene de hadde bodd før de ble deportert. $M$ ange av dem som overlevde $G$ ulagleirene, ble utsatt for kontinuerlig forfølgelse og K G B-raziaer etter at de kom tilbake fra Sibir.

Tidl igere politiske fanger og deporterte fikk ikke adgang til høyere utdanning. O fte var det bare ved hjelp av nære slektninger at de klarte å skaffe seg fast arbeid. De var nødt til å skjule sin fortid for kollegene sine fordi de risikerte å miste jobben. Dersom de snakket om sin deportasjon og de sibirske arbeidsleirene i all offentlighet, risikerte de dessuten å utsette familiene sine for forfølgel se. Det førte til at ofrene for den sovjetiske undertrykkingen ble gjenstand for traumatiske opplevel ser over en usedvanlig lang periode, nemlig i flere tiår.

\section{Benektelse}

A ndre verdenskrig endte som kjent med at de allierte seiret. Etter krigen ble nazismen fordømt som en kriminell ideologi, og krigsforbrytere ble dømt og straffet. 0 frene ble identifisert, og lidelsene de hadde vært utsatt for ble erkjent. Det har pågått en kontinuerlig prosess med å gi oppreisning for skadene de led. En omfattende forskning om traumatiske opplevelser kom i gang takket være en vedvarende innsats fra forskere på mange felt, og forskningen fortsetter den dag i dag.

Det andre av det tjuende århundrets totalitære regimer, nemlig kommunismen, skulle fortsette å bestå i nesten femti år til etter krigen, og er ennå ikke blitt stemplet som kriminell etter Sovjetunionens fall. Det råder fortsatt ambivaIente holdninger til sovjetregimet i de postkommunistiske landene og likeens i den vestlige verden. Ja, i Russland benektes det til og med at de baltiske statene var okkupert. Kampen mot kommunismen er ennå ikke fullført fordi det gjenstår å fordømme den som en forbrytelse mot menneskeheten. "Kommandanten i A uschwitz konsentrasjonsleir ble hengt, mens kommandanten i O zerlag hever pensjon som oberst." (A . B rossat, sitert av Kubilius, 2003 b, s. 125). Det gjør at mangelen på en omfattende og grundig evaluering av en ikke altfor fjern fortid fortsatt er et problem.

\section{Manglende forskning}

Etter at andre verdenskrig var over, begynte man i Vesten å drive seriøs forskning på de langvarige psykologiske og psykopatologiske effektene nazistenes undertrykking hadde på sine ofre. Studier har vist at traumatiske opplevelser under krig og politisk undertrykking kan gi alvorlige og langvarige somatiske, psykologiske og psykopatologiske virkninger. Disse virkningene kan ikke sies å ha noen sammenheng med en personlig disposisjon, ettersom personer som tidligere hadde vært fullstendig sunne og friske, ble plaget av psykiske symptomer på grunn av sine traumatiserende opplevel ser - frykt, nervøsitet, depresjon, nattlige mareritt, økt irritabilitet og aggresjon, samt nedsatt arbeidsevne. N oen av ofrene fortsatte til og med å være plaget av disse virkningene resten av livet.

$H$ va vitenskapelig forskning angår, skaper den fornektelsen og ambival ensen som hersker med hensyn til kommunismens forbrytelser, en alvorlig ubalanse. M ens en god del forskning er blitt viet til de traumatiske opplevel sene til H olocaustofrene, krigsskadde fra andre verdenskrig og medlemmer av antinazistiske 


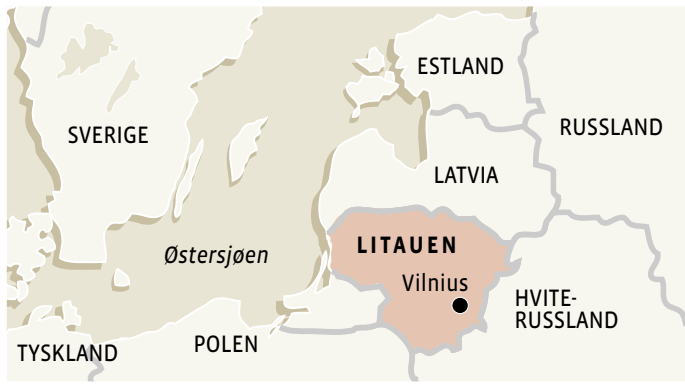

motstandsbevegelser, har det vært drevet lite forskning på traumer i post-kommunistiske land og især i de tidligere sovjetrepublikkene. Så vidt vi kjenner til, er slike studier nærmest ikke-eksisterende i de tidligere sovjetrepublikkene. Det er bare i Latvia at det forholdsvis nylig er blitt laget en oversikt over dem som ble ofre for undertrykking (Vidnere $\&$ N ucho, 2000). I 2000 gjennomførte vi den aller første studien av langtidsvirkningene av politisk undertrykking i Litauen ( $G$ ailiene \& Kazlauskas, 2005; Kazl auskas, 2006).

\section{Ofre for undertrykking}

I dag finnes det omkring 53000 personer i Litauen som har status som ofre for politisk undertrykking, slik dette er definert i republikken Litauens lover om den legale statusen til personer som led under okkupasjonene fra 1939 til 1990. 1354 personer som hadde vært undertrykt, deltok i studien. D eltakerne ble plukket ut gjennom et tilfeldighetsutvalg fra de offisielle listene over alle som hadde vært ofre for undertrykking under de okkuperende regimene. Svarraten lå på 80 prosent. Kontrollgruppen $(\mathrm{N}=119)$, som rent aldersmessig tilsvarte dem som hadde vært ofre for undertrykking, bestod av personer som ikke hadde formell status som ofre for undertrykking. N oen av dem som tilhørte denne gruppen, rapporterte likevel at de hadde lidd under sovjetisk eller nazistisk undertrykking, og svarene deres ble derfor holdt utenfor.

Spørreskjemaet omfattet spørsmål om demografiske data, traumatiske opplevelser (knyttet til undertrykking, bel astende livshendelser - den første delen av den litauiske versjonen av $\mathrm{H}$ arvard Trauma Q uestionnaire), innvirkninger på fysisk og psykisk helse (egenvurdering av helse og virkninger av undertrykking på hel sen - den litauiske versjonen av Trauma Symptom Checklist [T SC -35]), beskytten de faktorer (spørsmål om sosiale, kognitive og eksistensielle faktorer, samt hva begrepet "traume" innebærer og Sense of Coherence Scale SO C).

A lle deltakerne hadde vært utsatt for undertrykking over en svært lang periode, nemlig fengsling på politisk grunnlag og/eller eksil ( gjennomsnittlig varighet var 7,4 år). D eres traumatiske opplevelser endte ikke med at de vendte tilbake fra fangenskapet eller deportasjonen. $M$ ange av dem (61 \%) var blitt møtt med fiendtlighet i hjemlandet og opplevde vanskeligheter med å bli reintegrert. Det var bare omkring 7 prosent av deltakerne som ikke rapporterte om noen store problemer med å til passe seg på nytt. Politisk forfølgelse av tidligere politiske fanger varte frem til Sovjetunionens sammenbrudd og gjeninnføringen av Litauens uavhengighet.

De traumatiske opplevelsene som de undertrykte personene har hatt, er langt

Tabell 1. Ofre for undertrykking i Litauen 1939-90.

Traumatiske opplevelser i livet til ofre samt i kontrollgruppen (i prosent)

\begin{tabular}{|c|c|c|c|c|c|}
\hline \multirow[t]{2}{*}{ Belastende livshendelser } & \multicolumn{4}{|c|}{ Undertrykte personer } & \multirow{2}{*}{$\begin{array}{l}\begin{array}{c}\text { Kontroll } \\
\text { gruppe }\end{array} \\
\mathbf{N}=\mathbf{1 1 9}\end{array}$} \\
\hline & $\begin{array}{l}\text { Politiske } \\
\text { fanger } \\
(\mathrm{N}=724)\end{array}$ & $\begin{array}{c}\text { Depor- } \\
\text { terte } \\
(\mathrm{N}=362) .\end{array}$ & $\begin{array}{l}\text { Andre }^{1} \\
(\mathrm{~N}=268)\end{array}$ & $\begin{array}{c}\text { Alle }^{2} \\
(\mathrm{~N}=1354)\end{array}$ & \\
\hline Alvorlig sykdom & 47,2 & 41,4 & 40,0 & 56,8 & 42,0 \\
\hline Tap av familiemedlem & 61,3 & 67,4 & 69,0 & 64,4 & 61,3 \\
\hline Voldelig overgrep* & 28,7 & 17,7 & 22,4 & 24,5 & 7,6 \\
\hline Voldtekt & 2,1 & 2,5 & 2,2 & 2,2 & 0,8 \\
\hline $\begin{array}{l}\text { Vitne til hendelse som medførte død } \\
\text { eller skade for andre* }\end{array}$ & 64,1 & 44,2 & 51,9 & 56,4 & 20,2 \\
\hline $\begin{array}{l}\text { Opplevd hendelse som } \\
\text { kunne ført til død eller skade* }\end{array}$ & 51,7 & 27,6 & 39,9 & 42,9 & 11,8 \\
\hline Tortur* & 73,8 & 15,2 & 24,6 & 48,2 & 5,0 \\
\hline Trusler* & 70,0 & 43,1 & 58,6 & 60,3 & 18,5 \\
\hline Nestendrukning & 9,4 & 12,7 & 8,6 & 10,1 & 15,1 \\
\hline Selvmordsforsøk & 9,7 & 5,0 & 7,1 & 7,9 & 4,2 \\
\hline Ran/tyveri & 28,3 & 29,6 & 28,0 & 28,5 & 22,7 \\
\hline Abort & 1,7 & 5,2 & 4,9 & 3,2 & 9,2 \\
\hline Skilsmisse* & 6,9 & 13,5 & 9,7 & 9,3 & 16,8 \\
\hline Seksuell vold & 1,9 & 2,8 & 1,5 & 2,1 & 0,8 \\
\hline Fysisk vold* & 54,0 & 18,0 & 23,5 & 38,3 & 12,6 \\
\hline Forsømt i barndommen & 6,6 & 14,4 & 22,8 & 11,8 & 7,6 \\
\hline Ydmykelse* & 64,2 & 52,2 & 64,9 & 61,0 & 13,4 \\
\hline Forfølgelse* & 59,8 & 41,7 & 58,6 & 54,7 & 7,6 \\
\hline $\begin{array}{l}\text { Familiehistorie med psykiske } \\
\text { lidelser }\end{array}$ & 6,8 & 6,1 & 10,4 & 7,3 & 8,4 \\
\hline Fravær av foreldre i barndommen & 26,0 & 30,7 & 26,0 & 31,6 & 21,8 \\
\hline Bilulykke & 10,0 & 11,0 & 7,1 & 9,6 & 11,0 \\
\hline Andre farlige uhell & 6,4 & 3,9 & 5,6 & 5,5 & 4,2 \\
\hline Andre belastninger, f.eks forræderi & 5,8 & - & - & 7,3 & 1,7 \\
\hline
\end{tabular}

1) Andre personer utsatt for undertrykking. 2) Summerte skåreverdier for alle personer utsatt for undertrykking, *Chi-kvadrat, $\mathrm{p}<0,01$. Sammenlikninger er gjort mellom gruppene 'Alle' og 'Kontrollgruppe'. mer smertefulle enn for dem i kontrollgruppen (tabell 1). En mye større del av dem hadde vært vitner til at andre døde eller ble skadet, hadde opplevd trusler om død eller skader for egen del og opplevd tortur, forføl gelse, trusler eller ydmykelser. Politisk undertrykking og forfølgelse fikk innvirkning på helsen deres $(86,7 \%)$, hindret dem i å nå sine yrkesmessige eller utdanningsmessige mål ( 83,4 $\%)$, og førte til tap av familiemedlemmer ( $55 \%$ ). Resultatene viste videre at $\mathrm{i}$ gruppen med overlevende etter politisk undertrykking ( $47 \%$ ) hadde betydelig flere PTSD - forstyrrelser. 


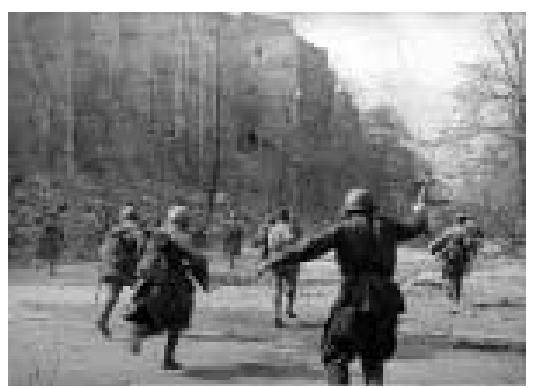

De som hadde vært utsatt for undertrykking, hadde i løpet av de to siste månedene opplevd mer mareritt og følelse av underlegenhet sammenlignet med kontrollgruppen.

\section{Psykososiale følger av okkupa- sjonene i perioden 1940-1990}

De som arbeider innenfor det psykiske helsevernet, må ikke bare ta med i betraktningen den virkningen de langvarige okkupasjonene har hatt for den enkelte, men også for hele samfunnet og dets mentalitet. Selv de menneskene i Litauen som ikke ble direkte utsatt for politisk undertrykking, levde i mange tiår i et okkupert land under et kommunistisk regime.

I en dagbok skrevet i 1948 og 1949, tegner kommandanten for partisandistriktet Dainava, Baliukevičius-D zukas, et dystert bilde av det okkuperte landet.

E n overveldende fattigdom! I kke en strime av håp om et lykkeligere liv. D en eneste underholdningen består i å drikke samogon ( hijemmebrent), ofte etterfulgt av fylleslagsmål. Landsbyen er fullstendig dominert av samogon. D et blir brent og drukket av alle, selv barn. D ruknet i et hav av blod, tårer og sort fortvilelse virker det som om nasjonen har funnet sin eneste trøst og flyktige nytelse i samogon. H vor mange idioter, forbrytere, degenererte personer, underslagere, prostituerte og tullinger vil disse fordømte årene bringe L itauen? N oen sier at årene med bolsjevikokkupasjon og kamp vil styrke nasjonen. D et som blir igjen vil være av stål, sier de. K anskje noen vil forbli sterke som stål, smeltet om og herdet i denne kampen. M en det vil være få av dem (Baliukevičius, 2002, s. 112).

Sovjetunionen var en totalitær stat der ingen kunne føle seg trygg. "I Sovjetunionen var alle borgere i sannhet like overfor dette til tider uforståelige totalitære maskineriet ... Den enkelte var totalt hjelpeløs. $\mathrm{H}$ ans mening spilte ingen rolle, hans valg spilte ingen rolle, og det var ingenting han kunne gjøre for å motsette seg systemet. I Sovjetunionen ble hver enkelt antatt å være skyldig. D enne følelsen av den ytterste hjelpeløshet må ha fulgt - og fulgte da også - alle borgere i Litauen gjennom femti år." (A liauskas, sitert av G ailiene, 2002, s. 125).

Enkelte av dem ble utsatt for ekstremt alvorlige traumer, for eksempel ble de sendt av sted for å slåss i kriger som ble utkjempet av Sovjetunionen (i A fghanistan, Tsjekkosl ovakia og andre land).

H vordan påvirket så okkupasjonene i 1940-årene og de femti årene under kommunistregimet samfunnet som helhet? $H$ va var de viktigste psykososiale føl gene? Landet mistet en tredel av borgerne sine. De som var igjen, levde under okkupasjonsregimet, der nedbrytingen av det personlige initiativ og privat ei endomsrett (nasjonalisering, kollektivisering), tapet av grunnlaget for samfunnets verdisystem ( f.eks. forfølgelse og ødeleggel se av kirken og religionen) og nedbrytingen av samfunnet (sentralisering, import av innfødt russisk manuell arbeidskraft ) fant sted. D et rammet i særlig grad menn, for i et jordbrukssamfunn som Litauen var eiendomsrett til jorda samt patriarkatet i familien svært viktige trekk ved det tradisjonelle livet. M ennenes rolle i samfunnet og familien, især på landsbygda, ble sterkt svekket. Den metoden de benyttet for å takle fortvilelse og hjelpeløshet, var inntak av alkohol, noe som førte til en høy forekomst av selvmord.

$\mathrm{N}$ oen av de alvorligste virkningene består fortsatt, nemlig en svært høy utbredelse av selvdestruktiv atferd, høyt alkoholkonsum og selvmord.
Litauen har sammen med de øvrige baltiske statene og R ussland verdens høyeste registrerte selvmordsrate. De siste åtti årene har dødelighet forårsaket av selvmord oppvist store variasjoner i Litauen. Da landet var en fri nasjon før krigen, var sel vmordsraten lav, og i perioden 1924 til 1939 var den gjennomsnittlige raten 8,1 per 100000 innbyggere. I noen europeiske land (Estland, Latvia, U ngarn, $\emptyset$ sterrike, Tsjekkoslovakia, Sveits) var selvmordsraten i den samme perioden faktisk fem til seks ganger så høy (Kelnik, 1989; G ailiene, 1998; G ailiene, 2004).

Tradisjonelt var selvmord ikke sosialt akseptabelt i Litauen. Den historiske anaIysen av tidligere tiders holdninger til selvmord i Litauen har i det store og hele vist at helt siden førkristen tid har litauernes holdning til selvmord vært tilbakeholden og temmelig negativ. De hedenske skikkelsene i litauisk mytologi ville aldri finne på å gjøre sel vmord - i motsetning til dem man finner i for eksempel gresk mytologi. H eller ikke forekom det noen selvmordsepidemier av den typen som man kjenner fra antikken. Da kristendommen vant innpass, virket det bare til å styrke de negative holdningene til sel vmord (Gailiene \& Ružyte, 1997)

U nder den sovjetiske okkupasjonen steg de årlige selvmordsratene jevnt og trutt fra omkring 16 per 100000 innbyggere i 1959 til omkring 36 per 100000 i 1984 (figur 1).

Figur 1. Selvmordsrater i Litauen 1930-1940 og 1959-2005

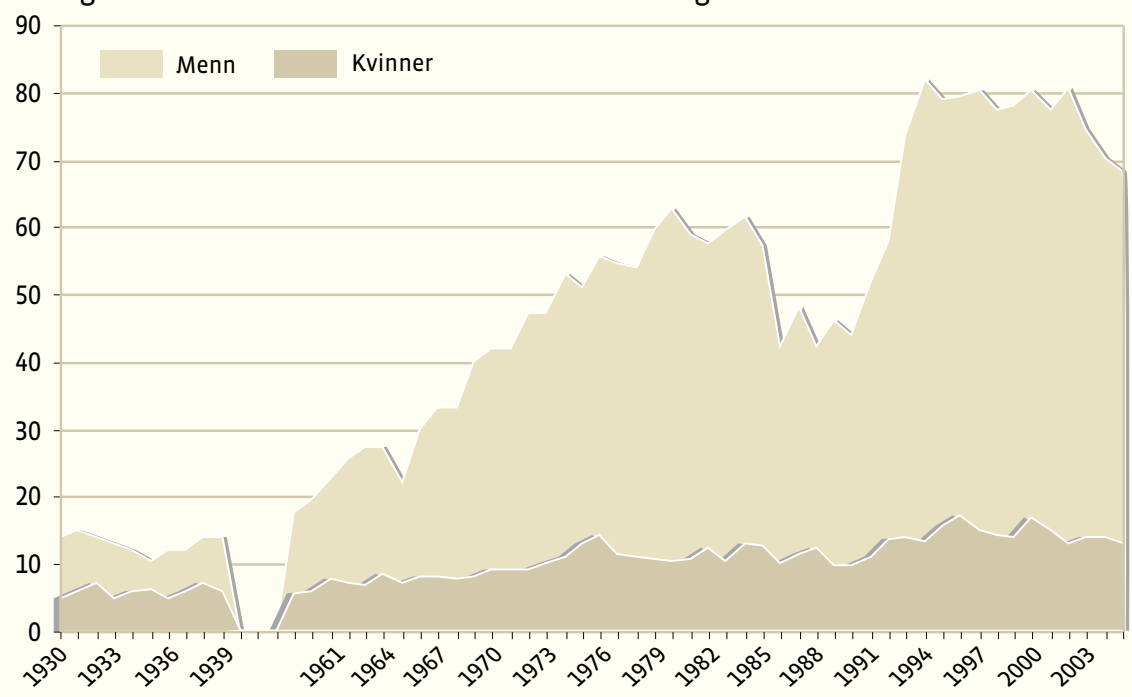


I perioden 1970-1984 økte selvmordsraten med 44,6 prosent. Da de politiske reformene i Sovjetunionen, perestrojka, kom i gang, sank den årlige selvmordsraten brått i 1986 fra 35,8 til 25,1 per 100 000. M ellom 1984 og 1988 oppviste selvmordsratene en fallende trend i alle de 15 republikkene i Sovjetunionen, særlig for menn (Värnik, 1997).

Den økningen i selvmordsraten som fant sted tidlig i 1990-årene, opptrådte parallelt med Sovjetunionens sammenbrudd og den gienvunne uavhengigheten til Litauen og de øvrige baltiske statene. Det som fulgte, var en tung overgang fra et system basert på kommunistideologi til et åpent samfunn og markedsøkonomi.

D e langvarige okkupasjonene, først av Sovjetunionen, deretter av nazistene og så av Sovjetunionen igjen, påvirket den evnen både den enkelte og grupper hadde til å mestre psykososialt stress og miljøforandringer. Den situasjonen som hele den baltiske regionen ble kastet ut i i 1940, kan nesten betegnes som en anal ogi fra det virkelige liv til tillært hjelpeløshet (Draguns, 1998). Sovjetunionens folkemord ødela hovedsakelig sosialt, politisk og økonomisk aktive personer og familiene deres. Passive holdninger og selvdestruktive mestringsstiler (f.eks. flatfyll, selvmordsatferd) spredte seg over hele det okkuperte landet, og især ute på landsbygda. De nyeste demografiske studiene som er gjennomført i Litauen, har avslørt at det "sovjetiske" dødelighetsmønsteret ikke har endret seg i overgangsfasen fra kommunisme til fri markedsøkonomi, som var kjennetegnet av et svært høyt nivå av prematur dødelighet og en økning i dødelighetsforskjellene mellom by og land. I 1999 nådde denne forskjellen i forventet levealder mellom by og land sitt rekordnivå på 5,8 år for menn og 3,3 år for kvinner. Selvmord er en svært sterkt medvirkende årsak til disse forskjellene i forventet levealder, særlig for menn (Jasilionis, 2003).

Lovgivernes holdninger endrer seg langsomt. En studie av enkelte europeiske land, blant dem Litauen, har vist en sammenheng mellom det aktuelle landets selvmordsrater og politikernes holdninger til selvmordsforebyggende tiltak. Politikere fra land med høyere selvmordsrater har en mer likegyldig holdning til selvmord (Salander-Renberg m.fl., 2003; Skruibis m.fl., 2008). I Litauen er det fortsatt lav bevissthet om betydningen av å ha en nasjonal strategi for selvmordsforebygging, og dette gjelder særlig blant politikere. Det gamle systemet for psykisk helsevern, nemlig et ekstremt medisinrettet psykisk helsevern, råder fortsatt. Den psykososiale komponenten blir fremdeles undervurdert og må fremdeles som regel gi tapt i kampen om begrensede ressurser (Paras, 2001). Det gjør at sel vmordsforebygging i Litauen ikke bare retter seg mot à øke hjelpen for risikoutsatte grupper, men også mot å minske de likegyldige holdningene til selvmord og øke oppmerksomheten rundt hvor viktig sel vmordsforebygging er.

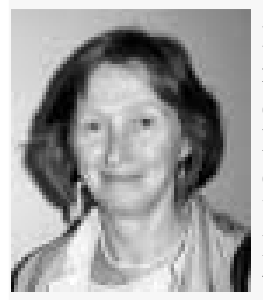

D anute $\mathbf{G}$ ailiene er professor i klinisk psykologi og leder for avdelingen for klinisk psykologi og organisasjonspsykologi ved U niversitetet i Vilnius i Litauen. $H$ un var den første til å ta initiativ til selvmordsforskning og -forebygging i Litauen, og hun har utgitt to bøker og skrevet en rekke artikler om suicidologi. Gailiene har i en årrekke vært Litauens nasjonale representant i IA SP (International A ssociation of Suicide Prevention), og hun er medlem av International A cademy for Suicide R esearch (IA SR).

(A rtikkelen er oversatt av Dag Biseth.)

\section{Referanser}

A nuauškas, A . (1996). Lietuviu tautos sovietinis naikinimas 1940-1958 metais. (T he Soviet Distruction of the Lithuanian $\mathrm{N}$ ation in 1940 1958). Vilnius: M intis.

Draguns, J.G . (1998). H omo sovieticus in the B altics? $\mathrm{H}$ ypothetical and actual manifestation in behavior and personality: their extent and limit. Paper presented at the III(XI) International Baltic Psychology Conference. Vilnius, June 30 July 3.

Gailiene, D. (1998). Jie neturejo mirti. Savizudybes Lietuvoje. (T hey should not have died. Suicides in Lithuania). Vilnius: Tyto al ba.

G ailiene, D. (2002). Politiniy represijy psichologiniai padariniai ( $\mathbf{T}$ he $\mathbf{A}$ ftermath of Political

R epression). $G$ enocidas ir rezistencija, 2,121-126.

G ailiene, D., Kaylauskas E. (2005). Fifty Years on: the L ong-term Psychological Effects of the soviet Repression in Lithuania. Gailiene D. (red.) The Psychology of $\mathrm{H}$ eavy Traumatisation: the A ftermath of Political Repression. Vilnius: A kreta, s. $67-107$
G ailiene, D. (2004) Suicide in Lithuania during the years of 1990 to 2002. A rchives of Suicide Research, 8, 389-395.

Gailiene, D. Ružyte, I. (1997). A ncient attitudes towards suicide in Lithuania. $\mathrm{N}$ ordic Journal of Psychiatry. 51, 29-35.

Jasilionis, D. (2003). Sociodemographic determinants of urban-rural differences in mortality in Lithuania. Summary of doctoral dissertation. Kaunas $U$ niversity of Technology and Institute for Social Research.

Kazlauskas, E. (2006). Long-term psychological effects of political repression. Summary of doctoral dissertation. Vilnius U niversity.

Kelnik, A . (1989). Suicide in Estonia. Papers by Tartu U niversity, 859, 64-85 (på russisk). Tallinn: Tartu U niversity.

Kubilius, V. (2003 b). Kelias i niekur per laztanti iliuziju leda ( $T$ he road to nowhere over the thin ice of illusion). M etai, 8-9:124-137.

Liongino Baliukeviciaus - partizano Dzako dienorastis: $1948 \mathrm{~m}$. birzelio $23 \mathrm{~d}$.- $1949 \mathrm{~m}$. birzelio $6 \mathrm{~d}$. (2002). Vilnius: Lietuvos gyventoju genocido ir rezistencijos tyrimo centras.

Püras D. (2001). Savizudybe - visuomenes sveikatos problema Lietuvoje. (Suicide as public health problem in Lithuania). I: D. Gailiene (red.)

Savizudybiu prevencijos idejos. Vilnius: Tyto al ba, p. 31-35.

Salander-R enberg, E., Fartacek, R., Fekete, S., G ailiene, D., H jelmeland, $\mathrm{H}$., $\mathrm{N}$ indl, T., $\mathrm{O}$ svath, P., Skruibis, P. (2003). Politicians attitudes towards suicide - a European interregional study. A bstracts of XXII W orld C ongress of the International A ssociation for Suicide Prevention (IA SP), 10-14 September 2003, Stockholm, 212:1.

Skruibis, P., G ailiene, D., H jelmeland, H ., Fartacek, R., Fekete, S., Knizek, B.L., O svath, P., Salander Renberg, E. \& Rohrer R.R. (2007). A ttitudes towards suicide among regional politicians in Lithuania, A ustria, $\mathrm{H}$ ungary, $\mathrm{N}$ orway and Sweden. In press.

Vidnere, M., N ucho, A .0. (2000). Latvian survivors of deportations. Riga: RaKa.

Värnik, A . (1997). Suicide in the B altic countries and in the former republics of the U SSR. Stockholm: Gotab.

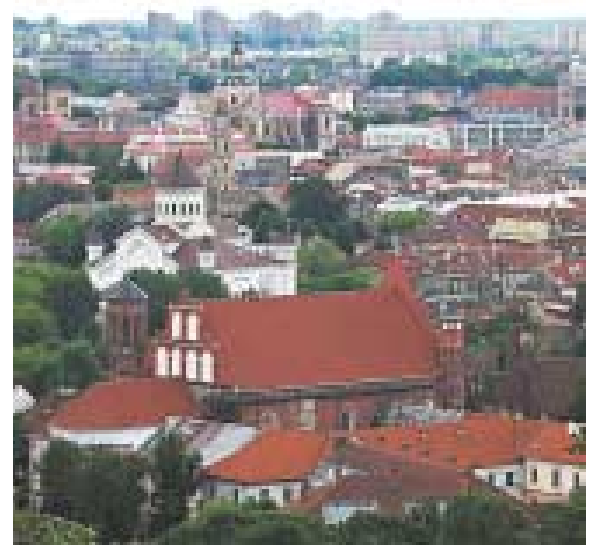

Fra Vilnius 